\title{
Immunoglobulin Heavy Chain Diversity Region
}

National Cancer Institute

\section{Source}

National Cancer Institute. Immunoglobulin Heavy Chain Diversity Region. NCI Thesaurus. Code $C 13443$.

The portion of the immunog lobulin heavy chain hypervariable region of immunoglobulin molecules that is found between the variable $(\mathrm{V})$ and joining $(\mathrm{J})$ elements. 